\title{
Endogenous Determination of FDI Growth and Economic Growth: The OECD Case
}

\author{
I. Hakan Yetkiner \\ Department of Economics, Izmir University of Economics, Izmir, Turkey
}

\begin{abstract}
This paper tests the endogenous relationship between FDI growth and economic growth using a panel dataset for 23 OECD countries for the period 1975-2004. In particular we estimate a twoequation simultaneous equation system with the generalized methods of moments (GMM) that treats economic growth and FDI growth as endogenous variables. We find that FDI growth and economic growth are significant determinants of each other. We also find that export growth rate and human capital are statistically significant determinants of both FDI growth and economic growth. Our findings lead us to conclude that FDI growth and economic growth have an endogenous relationship.
\end{abstract}

Keywords: FDI growth, economic growth, Panel Data, GMM

JEL Classification: C33, O5, F21. 


\section{Introduction}

World Bank statistics show that worldwide FDI grew on average 23.4 percent per annum between 1970-2006 and reached 1.4 trillion dollars in 2006. In the same period, the world GDP experienced on average a three percent growth rate per annum. The free movement of capital along with stable growth in recent decades suggests that there may be some positive relationship between FDI growth and economic growth. This relationship can be interpreted in three ways: (i) FDI is made in economies that have high long-run growth rates, (ii) FDI enhances higher long-run growth rates, (iii) FDI and economic growth affect each other simultaneously. The answer to which explanation is more applicable is especially important for policy makers of FDI recipient economies. For example, in the case of developing countries, many policy makers seem to believe that increasing FDI inflows is a prescription for achieving dramatic long-run growth rates. However, if economic growth precedes FDI growth, or if FDI growth and economic growth determine simultaneously each other, the volume of FDI expected by these policy makers will not be realized at the level they expect without having high growth rates. Besides policy concerns, there is a technical concern. It is important to determine whether FDI growth rate precedes economic growth, or vice versa, or whether the two determine each other simultaneously; without this information, the reliability of uni-directional analysis cannot be assured.

As stated above, one possible direction of causality is from FDI to economic growth. On theoretical grounds, it is argued that FDI may positively affect growth because it lowers rental rate of capital, increases production via enhancing labor productivity, and introduces new technologies embedded in the capital by moving capital from capital-rich countries to capital-scarce economies. Studies underlining these features of FDI are Hyun (2006), Hsiao 
and Hsiao (2004), Zhang (2001) and Duttaray (2001), among others. In contrast, other studies argue that, in supporting its own interests, FDI may discourage competition and even corrupt the development path of a country. Most empirical works, however, have found that FDI has a positive impact on economic growth. For example, Papanek (1973), Balasubramanyam et al. (1996), Borensztein et al. (1998), Balasubramanyam et al. (1999), Berthelemy and Demurger (2000), Obwona (2001), Reisen and Soto(2001), Zhang and Ram(2002), Massoud (2003), Bengoa and Sanchez-Robles (2003), Basu et al. (2003), Saha (2005), Li and Liu (2005), Johnson (2006), and Basu and Guariglia (2007) found that FDI has a positive impact on economic growth. In contrast, a relatively small number of studies, such as Fry (1993) and Bornschier et al. (1978), found that FDI may deteriorate economic growth as it may distort the development path of FDI-receiving economy. Interestingly, some other studies like Alfaro et al. (2002), Carkovic and Levine (2002), Durham (2004), and Herzer et al. (2008) found that there is no direct relationship between FDI and economic growth.

The alternative direction of eausality that economic growth may be a determinant of FDI is also a plausible conjecture. On theoretical grounds, advocates of the idea that economic growth has positive impact on FDI argue that higher growth rates of an economy stimulate the growth in demand, which implies greater profitability opportunities for inflowing capital. Hence, FDI sources may prefer faster-growing countries. On the other hand, opponents argue that lower growing economies may imply higher profitability opportunities for capital, given that these economies are capital-scarce and labor abundant. Empirical research on the issue shows mixed results; on the one hand, works such as Chowdhury and Mavrotas (2006), Saha (2005) and Choe (2003) found that higher growth rates attract more FDI. On the other hand, studies including Hansen and Rand (2006), Hsiao and Hsiao (2004) and Mencinger (2003) argue that fast-growing countries attract little FDI. 
It would be technically inappropriate to assume one-way causality when there is indeed a bi-directional one, as this would lead to unreliable results. Therefore, this study takes into consideration both possible directions of causality in a simultaneous equation system for the case of the OECD countries. The simultaneous equation setup allows us to treat FDI growth and economic growth variables endogenously. This is also supported by the causality studies such as Chowdhury and Mavrotas (2006) and Choe (2003), which have shown evidence for bi-directional causality between FDI and economic growth. Heuristically speaking, this approach is rare in the literature; most empirical studies focus only one particular direction of determination. In our simultaneous equation model, we estimate the determinants of FDI and economic growth for OECD countries through a panel data analysis. In particular, following Saha (2005) and Li and Liu (2005), we use Generalized Methods of Moments (GMM) estimation technique in a panel dataset for OECD countries. We believe that it is more appropriate to run FDI growth against economic growth, instead of FDI inflow or FDI stock (sum of FDI inflows). This is another innovation in our paper. Firstly, running a level value (FDI inflow or FDI stock) against percentage (economic growth rate) is not proper in a simultaneous equation system. Secondly, as long as FDI inflow or FDI stock is growing, percentage change of the level value would capture the same regularity. We consider OECD countries in this research because (i) the FDI data is extensive and reliable, (ii) they consist mainly of developed countries, a better representative of long-run FDI growth and economic growth rates.

The organization of the paper is as follows. Section 2 first describes the data and its limitations and follows with a discussion of the simultaneous equation system. Section 3 presents the findings of the model and its implications. The last section provides some concluding remarks. 


\section{Data, Method and Limitations}

\subsection{Data}

FDI inflows data were retrieved from World Development Indicators Online Database. Raw FDI data were in current US\$. Real FDI per capita data were formed using population statistics, collected from Penn World Table Database, and CPI, collected from World Development Indicators Online Database. FDI per capita growth rates were calculated simply from per capita real FDI. A similar procedure was applied for determining export growth rates. Firstly, exports of goods and services data were collected from WDI Online Database. Next, per capita exports values were calculated using population data from Penn World Table, and growth rates of export per capita were found. Growth ràtes of per capita GDP values were directly retrieved from the WDI Online Database. Finally, human capital data were collected from Barro-Lee Dataset, which consists of post-secondary education levels of the adult population.

Our data set covers the 1975-2004 period for 23 OECD countries, consisting of Australia, Austria, Canada, Denmark, Finland, France, Germany, Greece, Iceland, Ireland, Italy, Japan, Mexico, Netherlands, New Zealand, Norway, Portugal, Spain, Sweden, Switzerland, Turkey, United Kingdom, and USA. Belgium and Luxembourg were eliminated from the data set due to the unreliability of their FDI data, resulting in a balanced panel data set sample with 690 observations.

\subsection{Simultaneous Equation System}

A simultaneous equation system consists of a number of structural equations involving several endogenous variables whose values are determined by exogenous variables and lagged values of variables, known as predetermined variables. After each of the endogenous 
variables is solved in terms of the exogenous and predetermined variables, we obtain a system of reduced form equations.

Although the implications of simultaneity for econometric estimation were recognized much earlier, e.g., Working (1926), the first major contribution to the area of estimating simultaneous equation system was made in 1943 by Trygve Haavelmo. According to Haavelmo (1943), if one assumes that the economic variables considered simultaneously satisfy several stochastic relations, it is not usually a satisfactory method to try to determine each of the equations separately from the data without considering the restrictions which the other equations might impose upon the same variables. That this is so is almost self-evident, for in order to prescribe a meaningful method of fitting an equation to the data, it is necessary to define the stochastic properties of all variables involved. Without this definition, the results obtained would be meaningless. In addition to this, the stochastic properties ascribed to the variables in one of the equations should, naturally, not contradict those implied by other equations. Finally, if the simultaneity is ignored and ordinary least squares applied, the estimates and consequent forecasts will be biased and inconsistent. In addition, tests of hypotheses will no longer be valid (Ramanathan, 1998).

Our illustrative framework suggests that FDI contributes positively to the growth rate of the FDI receiving economy, and that positive growth rate stimulates FDI inflows positively, showing that theoretically, there is a bi-directional relationship between variables. Hence, we need to consider the determination of FDI growth and economic growth in relation to each other as it would not be appropriate to use unidirectional relationships between these variables. 


\section{Econometric Analysis}

In this part we present the results of the simultaneous equation system analysis. The simultaneous equation system is composed of two equations:

$$
\begin{aligned}
& g_{F D I, i t}=\beta_{0}+\beta_{1} g_{Y, i t}+\beta_{2} g_{X, i t}+\beta_{3} h c_{i t}(-5)+\beta_{4} g_{F D I, i t}(-1)+u_{i t} \\
& g_{Y, i t}=\alpha_{0}+\alpha_{1} g_{F D I, i t}+\alpha_{2} g_{X, i t}+\alpha_{3} h c_{i t}(-5)+\alpha_{4} g_{Y, i t}(-1)+v_{i t}
\end{aligned}
$$

In (10a), $g_{F D I, i t}$ is the growth rate of foreign direct investment of the $\mathrm{i}^{\text {th }}$ country at time $\mathrm{t}, g_{Y, i t}$ is the growth rate of GDP, $g_{X, i t}$ is the growth rate of exports, $h c_{i t}(-5)$ is five year lagged value of human capital and $g_{F D I, i t}(-1)$ is one year lagged yalue of FDI growth rate and $u_{i t}$ is error term. In (10b), $g_{Y, i t}(-1)$ is one year lagged value of GDP growth rate and $v_{i t}$ is error term. The growth rate of exports is the annual percentage change of goods and services exports, the GDP growth rate is defined as the annual percentage change in GDP, and the FDI growth rate is the growth rate of foreign direct investment inflows to countries. Finally, the human capital variable is the five-year lagged values of the post-secondary education rate of the adult population. We consider that lagged education levels have a definite effect on FDI inflow and economic growth rate; in other words, time elapses before human capital begins to affect FDI growth and economic growth. As Barro-Lee Dataset education statistics are for five-year periøds, we five-year lagged values of this variable were taken.

Before the analysis, we undertook unit root tests of series in order to avoid "artificial regression" problem. There are different approaches to unit root tests. Our results with these alternative approaches are shown in Annex C. Unit root test results prove that our series are stationary series, i.e., they involve no unit root problem. The following table shows the 
estimation results of our simultaneous equation system which was estimated by diverse econometric models.

Table 1: Estimation Results of the Simultaneous Equation System

\begin{tabular}{|c|c|c|c|c|c|c|}
\hline & \multirow{2}{*}{$\begin{array}{l}\text { Dependent } \\
\text { Variable }\end{array}$} & \multicolumn{5}{|c|}{ Independent Variable } \\
\hline & & Constant & $\mathbf{g}_{\mathbf{Y}}$ & $\mathbf{g}_{\text {FDI }}$ & $\mathbf{g}_{\mathbf{x}}$ & hc(-5) \\
\hline $\begin{array}{l}1 \\
(\mathrm{OLS})\end{array}$ & $g_{F D I}$ & $\begin{array}{c}-133.01 \\
(-0.54)\end{array}$ & $\begin{array}{l}76.62 \\
(1.50)\end{array}$ & - & $\begin{array}{c}9.10 \\
(0.99)\end{array}$ & 14.39 \\
\hline $\begin{array}{l}2 \\
\text { (TSLS) }\end{array}$ & & $\begin{array}{c}-364.94 \\
(-1.10)\end{array}$ & $\begin{array}{c}164.76 \\
(1.45)\end{array}$ & - & $\begin{array}{c}-15.22 \\
(- \\
0.99)\end{array}$ & $\begin{array}{c}-3.69 \\
(- \\
0.13)\end{array}$ \\
\hline $\begin{array}{l}3 \\
\text { (3SLS) }\end{array}$ & & $\begin{array}{c}- \\
801.05^{\star * *} \\
(-2.57)\end{array}$ & $\begin{array}{c}378.74^{\star \star \star} \\
(3.85)\end{array}$ & & $\begin{array}{l}26.50^{*} \\
(1.82)\end{array}$ & $\begin{array}{c}1.14 \\
(0.04)\end{array}$ \\
\hline
\end{tabular}

The first model uses the Ordinary Least Squares (OLS) estimation method to identify the first and second equations. t-statistics of all independent variables in the first equation are insignificant for $1 \%, 5 \%$, and $10 \%$ levels of significance. In the second equation, t-statistic of $g_{F D I}$ and $h c(-5)$ is insignificant at all levels, while $g_{X}$ is significant at $1 \%$ level. Test results indicate us that OLS regressions do not produce statistically reliable/significant results.

In the second model, Two Stage Least Squares Method (TSLS) was used to estimate the system. The results indicate that t-statistics of $g_{Y}, h c(-5)$ and $g_{X}$ in the first equation are insignificant, Moreover, $h c(-5)$ is significant only at the $10 \%$ level in the second equation; $g_{X}$ is significant at the $5 \%$ level, and $g_{F D I}$ is significant at the level of $1 \%$.

In the third model, Three Stage Least Squares (3SLS) estimation technique was used in order to estimate the system. $h c(-5)$ is insignificant both in the first equation and the second equation. On the other hand, in the first equation, $g_{X}$ is significant at the $10 \%$ level 
and $g_{Y}$ is significant at the $1 \%$ level. Moreover in the second equation of the system, while $g_{X}$ is significant at the 5\% level, $g_{F D I}$ shows significance for the level of $1 \%$.

\section{[The rest will be completed]}

\section{Concluding Remarks}

[To be completed]

\section{References}

Alfaro, L., Chanda, A., Kalemli-Ozcan, S. and Sayek, S. (2002). "FDI and Economic Growth: The Role of Local Financial Markets". http://www.people.hbs.edu/lalfaro/JIEfinall.pdf Anderson, James E. "A Theoretical Foundation for the Gravity Equation", The American Economic Review, Vol. 69, No. 1 (Mar., 1979), pp. 106-116.

Balasubramanyam, V.N., Salisu, M. and Sapsfort, D. (1996). "Foreign Direct Investment and Growth in EP and is Countries". The Economic Journal. Vol. 106. No. 434. pp: $92-105$.

Balasubramanyam, V.N., Salisu, M. and Sapsford, D. (1999). "Foreign Direct Investment as an Engine of Growth". The Journal of International Trade and Economic Development. 8:1. pp: $27-40$.

Barro, R.J. and Lee, J-W. (2000). "International Data on Educational Attainment: Updates and Implications”. CID Working Paper No.42. Harvard University.

Barro, R.J. and Sala-I Martin, X. (2005). Economic Growth. The IMT Press.

Basu, P. and Guariglia, A. (2007). "Foreign Direct Investment, Inequality and Growth". Journal of Macroeconomics 29. pp: $824-839$. 
Basu, P., Chakraborty, C. and Reagle, D. (2003). "Liberalization, FDI, and Growth in Developing Countries: A Panel Cointegration Approach”. Economic Inquiry. Vol. 41. No. 3. pp: $510-516$.

Bengoa, M. and Sanchez - Robles, B. (2003). "Foreign Direct Investment, Economic Freedom and Growth: New Evidence From Latin America”. European Journal of Political Economy. Vol. 19. pp: $529-545$.

Berthélemy, J-C. and Démurger, S. (2000). "Foreign Direct Investment and Economic Growth: Theory and Application to China". Review of Development Economics. 4(2). pp: $140-155$.

Borensztein, E.; Gregorio, J-De. and Lee, J.W. (1998). "How does Foreign Direct Investment Affect Economic Growth?”. Journal of International Economics. Vol. 45. pp: 115 - 135.

Bornschier, V. (1984). "The Role of MNCs in Economic Growth - Reply to Szymanski". Journal of Conflict Resolution. Vol. 28. No.1. pp 157-164.

Bornschier, V., Chase-Dunn, C. and Rubinson, R. (1978). "Cross-national Evidence of the Effects of Foreign Investment and Aid on Economic Growth and Inequality: A Survey of Findings and a Reanalysis". The American Journal of Sociology. Vol.84. No:3. pp:651 - 683. Carkovic, M. and Levine, R. (2002). "Does Foreign Direct Investment Accelerate Economic Growth?".

Choe, J. I. (2003). "Do Foreign Direct Investment and Gross Domestic Investment Promote Economic Growth?”. Review of Development Economics. Vol. 7(1). pp: 44 - 57.

Chowdhury, A. and Mavrotas, G. (2006). "FDI and Growth: What Causes What?”. United Nations University.

De Mello, L. R. (1999). “Foreign Direct Investment-Led Growth: Evidence From Time Series and Panel Data”. Oxford Economic Papers. Vol. 51. pp: 133 - 151. 
Durham, J.B. (2004). “Absorptive Capacity and the Effects of Foreign Direct Investment and Equity Foreign Portfolio Investment on Economic Growth”. European Economic Review 48. pp: $285-306$.

Duttaray, M. (2001). "Essays on Foreign Direct Investment and Growth: Causality and Mechanism".

Firebaugh, G. (1992). The American Journal of Sociology. Vol. 98. No.1. pp. 105-130.

Fry, M. J. (1993). "Foreign Direct Investment in a Macroeconomic Framework - Finance, Efficiency, Incentives, and Distortions". The World Bank International Economics Department. Working Papers. WPS 1141.

Haavelmo, T. (1943). “The Statistical Implications of a System of Simultaneous Equations”. Econometrica. Vol. 11. No:1. pp: 1-12.

Hansen, H. and Rand, J. (2006). "On the Causal Links Between FDI and Growth in Developing Countries". University of Copenhagen and Development Economics Research Group. Copenhagen.

Helpman, E. and P. Krugman, 1985, Market Structure and Foreign Trade; Increasing Returns, Imperfect Competition, and the International Economy. Cambridge MA/ London: MIT Press. Hermes, N. and Lensink, R. (2003). "Foreign Direct Investment, Financial Development and Economic Growth”, Journal of Development Studies. 40:1. pp: $142-163$.

Hsiao, F.S.T. and Hsiao, M-C.W. (2006). "FDI, Exports and GDP in East and Southeast Asia - Panel Data Versus Time-Series Causality Analysis". Journal of Asian Economics 17. pp: $1082-1106$.

Hyun, H-J. (2006). "Foreign Direct Investment and Economic Growth in Developing Countries”. Indiana University.

Johnson, A. (2006). “The Effects of FDI Inflows on Host Country Economic Growth". CESIS Electronic Working Paper Series. Paper No. 58. 
Li, X. and Liu, X. (2005). "Foreign Direct Investment and Economic Growth: An Increasingly Endogenous Relationship”. World Development. Vol. 33. No:3. pp: 393 - 407. Mencinger, J. (2003). "Does Foreign Direct Investment Always Enhance Economic Growth?”. KYKLOS. Vol. 56. pp: 491 - 508.

Nair - Reichert, U. and Weinhold, D. (1999). “Causality Tests for Cross - Country Panels: New Look at FDI and Economic Growth in Developing Countries".

Obwona, M. B. (2001). "Determinants of FDI and their Impact on Economic Growth in Uganda”. African Development Bank Economic Policy Research Centre.

Papanek, G. V. (1973). “Aid, Foreign Private Investment, Savings and Growth in Less Developed Countries". The Journal of Political Economy, Vol. 81. No.1. pp:120 - 130.

Ram, R. and Zhang, K. H. (2002). "Foreign Direct Investment and Economic Growth: Evidence From Cross - Country Data for the 1990s". Economic Development and Cultural Change. Vol. 51. pp. 205.

Ramanathan, R. (1998). "Introductory Econometrics with Applications". Fourth Edition. The Dreyden Press. Fort Worth - USA.

Saha, N. (2005). "Three Essays on Foreign Direct Investment and Economic Growth in Developing Countries". Utah State University. Logan, Utah.

WORLD "World Development Indicators Online". http://devdata.worldbank.org/dataonline, Retrieved at: 15.03 .2008

Working, E.J. (1927). "What Do Statistical Demand Curves Show?”. The Quarterly Journal of Economics. Vol.41. No.2. pp: 212 -235.

Zhang, K.H. (2001). “Does Foreign Direct Investment Promote Economic Growth? Evidence From East Asia and Latin America”. Contemporary Economic Policy. Vol. 19. No.2. pp. 175 -185 . 